\title{
BMT Al-Ishlah Cirebon as a model of Islamic financing for poverty reduction and development
}

\author{
Oon Konaah ${ }^{1, *}$ \\ ${ }^{1}$ Lecturer at the Sharia Economics Program, College of Islamic Economics (STEI) Al-Islah, Cirebon, West Java, \\ Indonesia and Secretary of the Sharia Economics Community (MES) of Cirebon \\ *Corresponding author: konaahoon1972@gmail.com
}

\begin{abstract}
Although in fact the conventional financial system has manifestly failed in the fair distribution of wealth, Islamic financial system in Indonesia is not yet a strong alternative financial system. Market share of Islamic financial institutions are still low, below 5\% with growth of $34 \%$ in 2015 . The data indicate the existence of problems in the implementation of the principles of Islamic finance though in terms of prospects it has big potential. Islamic economic principles which have inherent values of justice, divinity, freedom and responsibility, should be the right system in a democratic economy for the economic empowerment of the poor. Some of the reasons for its slow implementation, based on field analysis are first, people are still accustomed to a conventional system that has been around longer; second,Islamic financial institutions are not ready to completely adopt the Islamic financial system in particular Profit \& Lost sharing (PLS); third, implementation of Islamic financial system tends to require relatively high operating costs. To contribute a solution, the author analyzed descriptivequalitatively the above problems in this paper. The author is a community development agency practitioners in an Islamic financial institution Baitul Maalwat Tamwil (BMT/House of Wealth and Business) in technical operations. This simple paper notes that Islamic financial institutions in Indonesia have not fully practice the principles of Islamic finance because of certain interests. However, there has existed in Indonesia an Islamic financial institution operating in accordance to the principles of Islam, which in practice is the empowerment of people out of poverty.
\end{abstract}

Keywords: Islamic/Sharia Finance/Banking, $\mathrm{BMT}$, poverty reduction, empowerment

\section{INTRODUCTION}

It has become clear that the interest system of conventional banks is a link of human exploitation. The chain of interestgrows bigger with the addition of standardized intervals on the costs of operations and development of financial institutions. The chain of interest occurs from the central bank's 6\% down to commercial banks' $12 \%$, down again to the rural banks' $24 \%$ until the tail end of the financial institutions, lending to microbusiness. The bank rate on the chain of exploitation is greater when it hits poor people who are not bankable. Islamic financial system is a system that is identified with the absence of interest but presenting profit sharing as an alternate, by the use of zakat (Islamic tax). In Islamic finance bank interest is replaced with business outcome, whereby both parties to a transaction, investors and managers, are ready to bear the possible profit or loss. Zakat collected from the enterprise is submitted to management agencies which allocate them to 8 specific social welfare issues.

Indonesians still have problems in understanding the Islamic financial system. They are used to the conventional system that has long existed. Understanding of the Islamic financial system is merely conversion of terms. This is in accordance with the historical process of the establishment of Islamic banks in Indonesia. Of 12 Islamic banks, 11 Islamic banks started as the conversion of conventional banks and the only bank establishedas sharia since its inception is Bank Muamalat Indonesia (BMI). Laymen 
identify the Islamic financial institutions/sharia banks as follows: that do not use the term interest, but "margin", the use Arabic names of products, but they do not really understand the meaning and differences, their perception of the margins on the lendingproducts in Islamic financial institutions are more expensive than conventional banks; their attitude is eclectic on comparing institutions, i.e. "saving money should bein Islamic banks, but borrowingcouldbe fromconventional banks". Public understanding of Islamic financial institutions above is a result of the information they get when they attend the Islamic banking/financial institutions.

The following products are distributed funds of Islamic banking in Indonesia in June 2016.

Table 1. Distribution of Indonesian Islamic banking funds (SPS Data Processed FSA 2016)

The data above show murabahah products is the main distribution of funds of Islamic banking in Indonesia. The above list is an indicator of doubt of the totality of Islamic banking to apply the principles of Islamic finance that use profit and lost sharing (PLS). The use of murabahah contract to finance the working capital rotation in business activity is a form of fraud and improper understanding of Islamic banks. For withdrawal customers/depositors are willing to apply Islamic banking products other than murobahah, namely mudharabah and musyarakah.

The common mistake is backed by information from sharia banks/financial institutions in Indonesia, where they are likely to only offer murabahah funding. Murabahah is a type of sales transaction that does not use the concept of profit and loss sharing (PLS). Murabahah produce a profit for the sharia bank / financial institution in the form of margin. Determination of the reference margin on murabahanis based on total operating expenses and costs of financial institutions. The attitude of financial institutions is more inclined to murabahah products in financing, an indication of minimum of trust of the lending community that feared business failure of repayment of the loan capital. For clarity of the discussion in this paper, I will attempt to answer three questions, as follows: 1 . Are the Principles of Islamic Finance already practiced? 2. Can Islamic Finance Practice helps in Poverty Reduction and Development? 3. How much has BMT Al-Ishlah Cirebon's Islamic
Finance practice helped in Poverty Reduction and Development?

\section{METHOD}

The method used in this paper is analytical description. Data sources data are statistical reports on Islamic banking and finance of 3-year period up to June 2016. These are compared with the financial statements BMT Al-Islahin the last 3 years $(2013,2014,2015)$. Financial analysis of the data reflects directly on the management of the BMT. This paper follows the framework of thought as follows: first, cite some of the principles of the theory of Islamic finance; second, verify the implementation of the principles of Islamic finance by analysis of financial data and interviews; third, presents the data of community development in Cirebon that for some time now is managed in integration with BMT.

\section{RESULTS}

\section{Are the Principles of Islamic Finance already practiced?}

Islamic values in all aspects of life have been written in the Holy Qur'an and other Islamic books. Tenets of the rule of law regulate human behavior between people, with the economy and the environment. For new muamalah (human interaction) problems that have not been written in the Qur'an or Sunnah (examples from the life of the Prophet Muhammad) solution is provided by way of ijtihad ("academic analysis") of experts in Islamic law while still referring to Qur'an and Sunnah. Muamalah basic laws permit or allow humans to make efforts for innovation and creativity. Products and technology are constantly evolving in socio-economic affairs, so these do not oppose the ethics stipulated in the Qur'an and Sunnah. The three main pillars of Islamic economics is the implementation of zakat, the prohibition of usury, and the prohibition maysir/gharar (gambling). Macroeconomically, systemic implementation of zakat will increase aggregate demand and encourage wealth flowing into investment; the prohibition of usury will ensure a steady/unabated flow of investment; while banning maysir will ensure investment flows to 
the real sector for productive purposes which ultimately will increase aggregate supply ${ }^{1}$.

In the implementation of Islamic economic activity both in real and financial sectors, the following four principles must be maintained, including: PLS $+\mathrm{HT}+\mathrm{Z}+\mathrm{W}^{2}$.

Profit and loss sharing (PLS): investment system based on the distribution of profits and losses between those who cooperate. Profit and Lost Sharing is a solution for the suppression of usury. The Islamic financial products that already exist today are as follows: Mudharabah, Musharakah, Murabahah, Salam, Istishna, Ijarah, Multi Qardh and other services.

Halal and Thoyib (HT): commodity produced is lawful and beneficial, both in the product itself and in the process of acquisition. Halal essence of an object has been clearly defined in the texts of the Qur'an and Sunnah. For example, food processed in the Islamic way or kosher food is correct for consumption, and only some of which are forbidden such as alcoholic beverages and pork products, among others. There are also prohibition against sex between men and women without marriage, disobedience to parents and of worshiping other godsexcept Allah. Halal is also required in the process of acquiring profits or ownership of property. Islamic set of ethics promote positive values such as the ban on stockpiling/hoarding, of cutting of open market cycles, gambling/uncertainty, dzolim (malicious) behavior, but it also recognizes that excessive regulation is restrictive. It recommends timely payment of debts, suggests recording transactions delay, the testimony/facilitation of the transaction, recommends to pay wages immediately and it suggests forgiveness. Some ethics above then became the standard indicator for Indonesian Ulema Council (MUI/Islamic Experts) in giving fatwa (recommendation) on business products and Islamic finance. Zakat (Z): both managers and financiers involved in the transaction issue zakat. In charity there is a balance of the impact of the financial system. Zakat funds deposited by the customer funding and lending is distributed through Islamic financial institutions that also manage the field of

\footnotetext{
${ }^{1}$ BI, Asykarya, Akad dan Produk Bank Syariah, Konsep dan Praktek di Berbagai Negara.(2006)

2 Murasa Sarkaniputra, Ruqyah Syariyah ; teori, model dan sytem Ekonomi Islam, 2009.
}

social services called Baitul Maal (BM/House of Wealth).

Weigh (W): wages must be paid before the sweat dried. It must be significant to worker entitlements on performance and meet the basic needs of workers. Wages in the Islamic economic system cannot be a simple function of (increased) productivity. To maximize profit (profit maximizing) workers become determinants through increasing the number of products that will have an impact on increasing the income of workers and bolster profitability. Instead of minimizing cost, wages do not become a variable that is reduced to the detriment or worker. This will be termed dzolim (malicious). Instead, managers use technology solutions or change business strategy to reduce operating costs.

Islamic finance is not a religious system. It can be used and operated by anyone and any community for poverty reduction programs and community economic development ${ }^{3}$. There are four basic categories of Islamic financial products. The first mode is based on cooperation such as musyarakah and mudharabah. Second trade based modes such as murabahah, musawamah, greetings and istisna. Third leasebased modes such as ijarah. The fourth model is charity-based and other services such as qardhhasan, wakalah, waqf, zakat and infaq.

\section{Can Islamic Finance Practice helps in Poverty Reduction and Development?}

Islamic financial institutions have two main roles, namely as a business entity (tamwil) and charity (maal). As a business entity, Islamic banks have several functions, namely as investment managers, investors and financial services. As investment managers, Islamic banks administer funds from clients/depositors/savers with the principle Wadi'ahdhamanahyad (surrogate), Mudharabah (profit sharing) or Ijarah (lease). As investors, Islamic banks channel funds through investment activities with the principle of sharing, purchase, or lease. As a provider of banking services, Islamic banks provide financial services, non-financial services, and agency services. Financial services, among

${ }^{3}$ Journal The International Seminar, empowering SMEs For Financial Inclusion and Growth, Mohammad Zubair 2013. 
others, are performed with the principle Wakalah (mandate), Kafalah (bank guarantee), Hiwalah (debt swap), Rahn (collateral debt or mortgage), Qardh (benevolent loans for bailouts), Sharf (sale and purchase of foreign exchange) and others. Non-financial services are in the form of a mandate Wadi'ahyad (safe deposit box) and agency services to the principle of Mudarabahmuqayyadah. Meanwhile, as a charity, Islamic banks have a social function as a fund manager for the collection and distribution of Zakat, Infaq (donation), and Sadaqah/alms (ZIS), as well as the distribution Qardhulhasan (benevolent loans). In general, financial institutions engaged in financial (monetary) sector in accordance with the provisions of BI (the Central Bank of Indonesia). Thus banks are not allowed to conduct business outside the core business, namely the financial sector. Based on several Islamic financial products, Islamic financial institutions in addition to conducting its business in the monetary core can also serve payment-related services such as insurance, mortgage, leasing and other business collaboration.

\section{Table 2. Islamic financial institutions, compiled} from various sources.

Baitul Maal Division besides charity services also conducts training of prospective customers that are recommended to Tamwil (productive loans) such as mustahik (deserving parties) for a smooth and honest return of Qardhulhasan. Islamic financial products were implemented in the time of Prophet Muhammad, at the time of his friends and the subsequent periods. Contemporary products that are still relevant to current times have been through the process of ijtihad of the scholars. From some of the above products, there are derivative products that are more specific.

\section{BMT Al-Ishlah Cirebon as an Islamic Finance Institution}

BMT Al-Islah,isan Islamic microfinance institution established in 1990. This Islamic financial institution is one of the business units of the Cooperative Society of the Islamic Boarding School (Koperasi Pondok Pesantren/ Kopontren) Al-Islah. The purpose of the cooperative is for capital raising and financial services for Kopontren (established in 1987). The Kopontren, a business entity of the Al-Islah
Foundation, was established with the goal of becoming a source of income and funds. At the time of establishment the capitalized compulsory deposits of the principal members was Rp10,000,000. Currently BMT Al-Islah has had 6 units of cash office in the district of Kuningan, Majalengka, Indramayu, Arjawinangun and Plumbonin Cirebon and the Head Office in the village of Bobos Cirebon, with total assets that has now reached Rp11,209,305,803.

\section{Funding for BMT Al-Ishlah Cirebon (AC)}

As microfinance institutions under the auspices of Islamic Cooperation, BMTAC collected funds from compulsory savings and membership fees. In addition there are other voluntary savings offered by savings products as needed by society. The total amount of deposits of members/customers BMT AC in 2015 amounted to $63 \%$ of the total funds. Funds from other third parties derived from shares in Al-Islah Cooperative are $13.8 \%$, an Islamic commercial banking fund is $10.8 \%$ and funds of the Association of Sharia Cooperatives are $14.5 \%$ of total funding of the BMT AC. Here are the names of members' savings type:

\section{Table 3. Types of BMT AC members' savings as of} 2015.

BMT surplus is distributed to shareholders in the form of sharing of margin/profit earned in accordance with the agreed ratio, net of expenses. According to the table above net profit sharing ratio to fund owners is $58 \%$ per year with variations of $69 \%$ in 2013, 48\% in 2014 and $64 \%$ in 2015. The annual net profit ratio is inconsistent, due to differences in the ratio of any product in accordance to the volume of business, amount of capital and length of lending period, and the need for supervisors' wage suitability that have been agreed in the contract.

Comparison between BMT and conventional system is as follows: total net profit sharing to owners of capital on average over 3 years is $58 \%$, would be equivalent to $12 \%$ of gross income, or equivalent to $3.6 \%$ of return to capital. Average operational cost is $79 \%$ of revenue. This indicates the high costs that reduce net profits, base for the profit sharing ratio. The high operational costs can be an arbitrary opportunity for financial managers to set ideal standards in the SOP with the approval of the owner of the funds. In the case above, since its 
inception the owner of funds were never assured of maximum profit. The following is the income statement of BMTAC 2015:

\section{Table 4. Income statement BMT}

The rest of the net profits, termed Operation Surplus (SHU/Sisa Hasil Usaha) is allocated as follows: capital reserves, earned income for (the general)members, wages for supervisors and administrators of the kopontren, BMTAC managers, employee benefits, social lobligations, regional development and external audit fee.

\section{Lending by BMT AC}

As for the distribution of funds or financing, at BMT AC as well as Islamic banking in Indonesia in general, Murabahah is the product selected by borrowers. This is due to a lack of understanding of the product and basic familiarity of the conventional products that have similarities with murabahah scheme. Besides, marketing and front office of BMT AC tend to offer Murabahah more than other products. This is a decision that is based on cautious management of third-party funds, minimum trust factor that leads less lending to customers. It is also simpler and not costly.

\section{Table 5. Lending Products of BMT $\underline{\text { AC }}$}

The margins set for BMTAC lending products are in the range of $1.8 \%-2 \% /$ month, as it is based on the total operating cost, which is as high as $79 \%$ of total revenue. BMTAC as a cooperative also determines the distribution of net income to specified stakeholders.

How much has BMT Al-Ishlah Cirebon's Islamic Finance practice helped in Poverty Reduction and Development?

Al-Ishlah Islamic Foundation Cirebon is founded in 1974 with the vision of creating a perfect Moslem generations achieving a dream community. In addition to providing education, from elementary to college, it also established economic institutions which have the goal of meeting the needs of community development by managing the funds held by the Foundation. BMT AC is the business entity that collects funds to offer financial solutions to the problems of financing Al-Islah's 8 units of educational institutions, 2 units of social institutions and 5 business units. The whole group saves money in BMTAC, which besides providing loans to members, also pay the salaries of all employees of Al-Islah, including staff of BMTAC. Indirectly BMT AC also plays a role in poverty reduction and community development in the area of Cirebon, West Java until 2015, with the following data:

\section{Table 6. BMT Empowerment}

\section{Outcome}

From the discussion above, a number of conclusions follow:

a. The principle of Islamic finance is very suitable for poverty alleviation programs and community development. Baitul Maal performs directlyin the field of community development and poverty alleviation problems, whileTamwil is the long-term empowerment of poor people to become independent. The absence ofinterest and its replacement with profit sharing eliminates exploitation among humans, but it requires strong commitment and transparency. The presence of zakat in Islamic finance principles is a solution to bridge thegap between the poor and the rich, between the owners offund and the managers, the financial institution and its members.

b. Conformity to the principles of Islamic finance inpractice has not been complete. This is because there is no readiness on people to fulfillthe conditions required by Islamic finance. Islamic financial institutions' lending productshave emphasized buying and selling contract (murabahah) because it is simpler and low-risk. High operating costs led to the determination of the margin on lending products to beas high as $1.8 \%-2 \%$ per month.

c. BMT Al-Islah in Cirebon regency, West Java Indonesia, has been able to participate in poverty reduction of 16471 people, through education saving program, retirement saving accounts, walimah, pilgrimage (Hajj), Qurban/sacrificiallambs, Eid and insurance. Tamwil (Business) Division has helped 1,610 SMEs through venture capital financing, the 
VIP Mobile agency supports502 agents and donations for social welfare issues through Baitul Maal has amounted toRp 354, 582, 680.

\section{REFERENCES}

Asykarya, "AkaddanProduk Bank Syariah, KonsepdanPraktek di Berbagai Negara". BI, Jakarta, 2006

Asykarya\& Diana Yumanita, "Bank Syariah ; gambaran umum". Pusat Pendidikan dan Studi Kebanksentralan (PPSK), BI, Jakarta, 2005.

Choudhury, Masudul Alam, "Contribution to Islamic Economic Theory". St. Martin's Press, New York, 1986.

OJK/The Financial Services Authority \& BI/Bank Indonesia, "Statistik Perbankan Syariah”. Jakarta, Juni 2016

Sarkaniputra, Murasa, "Ruqyah Syar'iyyah ; teori, model dan sistem ekonomi Islam". STEI Al-Ishlah Cirebon Press, 2009.

UIN-SU, "Analisis konsistensi penerapan prisip bag sedkit hasil pad akuntansi bank syariah", 2016. http://repository.uinsu

Wiroso, "Produk Perbankan Syariah". Jakarta LPFE, Usakti 2011

Zubair, Muhammad, "Empowering SMEs For Financial Inclusion and Growth". Journal of the International Seminar, 2013.

Table 1. Distribution of Indonesian Islamic banking funds (SPS Data Processed FSA 2016)

\begin{tabular}{lll}
\hline Akad & Million Rp & Percent \\
\hline Mudharabah & 182.677 & $3 \%$ \\
Musyarakah & 764.862 & $12 \%$ \\
Murabahah & 4.927 .903 & $78 \%$ \\
Salam & 14 & $0 \%$ \\
Istishna & 9.388 & $0 \%$ \\
Ijarah & 7.508 & $0 \%$ \\
Qardh & 139.772 & $2 \%$ \\
Multijasa & 431.711 & $6 \%$ \\
\hline Jumlah & 6.463 .834 & 100 \\
\hline
\end{tabular}


Table 2. Islamic financial institutions, compiled from various sources

\begin{tabular}{|c|c|c|c|}
\hline TAMWIL & & & BAITL MAAL \\
\hline Islamic Finance & Islamic & Islamic Finance & Charity Fund \\
\hline Funding & $\begin{array}{l}\text { Finance } \\
\text { Lending }\end{array}$ & Service & \\
\hline $\begin{array}{l}\text { Principle of } \\
\text { Mudharabah }\end{array}$ & $\begin{array}{l}\text { Revenue- } \\
\text { Sharing }\end{array}$ & & Compensation Fund \\
\hline Saving & & - Wakalah, Kafalah, & Fund \\
\hline $\begin{array}{l}\text { Deposito/Investasi } \\
\text { Obligasi }\end{array}$ & $\begin{array}{l}\text { Mudharabh } \\
\text { Musharakah }\end{array}$ & $\begin{array}{l}\text { Ujr, Qardh, Sharf, } \\
\text { Rahn }\end{array}$ & Lend ZIS \\
\hline Prinsip Wadiah & Purchase & Non-financial & Fund trustee \\
\hline $\begin{array}{l}\text { yad dhamanh } \\
\text { - Giro }\end{array}$ & Patterns & Services & Oardhul Hasan \\
\hline - saving & $\begin{array}{l}\text { Murabahah } \\
\text { - Salam } \\
\text { - Istishna }\end{array}$ & $\begin{array}{l}\text { - Wadi'ah yad } \\
\text { amanah }\end{array}$ & \\
\hline Prinsip Ijarah & principles & Services Agency & \\
\hline - Obligasi & $\begin{array}{l}\text { Rental } \\
\text { - Ijarah } \\
\text { - Ijarah wa } \\
\text { Iqtina }\end{array}$ & $\begin{array}{l}\text { Mudharabh } \\
\text { muqayyadh }\end{array}$ & \\
\hline
\end{tabular}

Table 3. Types of BMT AC members' savings as of 2015

\begin{tabular}{llll}
\hline No. & Product Name & Rp millions & Deposit Ratio \\
\hline 1. & Deposits required & 1.495 & $2.88 \%$ \\
2. & Deposits & 1.493 & $0.53 \%$ \\
3. & Saving of principal candidate members & 4.709 & $0.52 \%$ \\
4. & Deposits walimah & 40 & $0.11 \%$ \\
5. & Saving for retirement & 0 & $0.00 \%$ \\
6. & Saving for education & 260 & $7.07 \%$ \\
7. & Saving for madinah & 4.360 & $62.98 \%$ \\
8. & Saving for Eid & 837 & $12.58 \%$ \\
9. & Saving for Qurban & 50 & $0.12 \%$ \\
10 & Saving for Hajj & 25 & $0.59 \%$ \\
10. & Saving for ZIS & 0 & $0.00 \%$ \\
11. & Saving for wadiah & 3.202 & $12.62 \%$ \\
12. & Saving for RAK & 0 & $0.00 \%$ \\
13. & Saving for VIP Mobile & 0 & $0.00 \%$ \\
\hline Amount & 16.471 & $100 \%$ \\
\hline
\end{tabular}

Table 4. Income statement BMT

\begin{tabular}{ll}
\hline Items & Percent \\
\hline Income & $29 \%$ of funding \\
Expenses \& Operational & $79 \%$ of Income \\
Cost & \\
Earning before Zakat & $21 \%$ of Income \\
(EBZ) & $2,50 \%$ of Income \\
Zakat & $21 \%$ of Income \\
Net income BMT & \\
\hline
\end{tabular}


Table 5. Lending Products of BMTAC

\begin{tabular}{llll}
\hline No & Product name & Rp millions & Ratio \\
\hline 1. & Mudharabah & 0 & $0.00 \%$ \\
2. & Musyarakah & 262 & $7.55 \%$ \\
3. & Murabahah & 1.064 & $71.15 \%$ \\
4. & Bai Bitaman Ajil & 0 & $0.00 \%$ \\
5. & Public Multi service & 1 & $0.61 \%$ \\
6. & Rahn & 0 & $0.00 \%$ \\
7. & Multi sevice & 137 & $7.90 \%$ \\
8. & Qordhul hasan & 124 & $9.51 \%$ \\
9. & Ijarah muntahia & 0 & $0.00 \%$ \\
& bitamlik & & \\
10 & Hawalah & 2 & $3.08 \%$ \\
\hline & Amount & 1.610 & $100 \%$ \\
\hline
\end{tabular}

Table 6. BMT Empowerment

\begin{tabular}{ll}
\hline Items & Quantity \\
\hline Member : & \\
Saving & 16.471 Accounts \\
Lending & 1.610 Accounts \\
Charity BM & Rp 354.582.680,- \\
Lending 3 Years & Rp 22.022.747.749,- \\
Employment & 35 persons \\
Agency of VIP Mobile & 502 persons \\
\end{tabular}

